\title{
DEBATING TOYNBEE'S THEORY OF CHALLENGE AND RESPONSE: CHRISTIAN CIVILISATION OR WESTERN IMPERIALISM?
}

\author{
F. Hale ${ }^{1}$
}

\begin{abstract}
In his 1952 Reith Lectures on the British Broadcasting Corporation, "The World and the West", the eminent London historian Professor Arnold Toynbee sought to explain inter alia why western European hegemony over much of the world was widely resented. His interpretation incorporated the "challenge and response" theory of successive civilisations which underlay his multi-volume A Study of History. Toynbee's lectures drew sharp criticism from many quarters, not least because he gave the impression that the era of Western hegemony was waning and that much of the momentum of world history was moving to the East. This in itself was a controversial perception in the Cold War. In some Christian circles, his overarching interpretation was rejected as historiographically flawed. In the ensuing debate, the prominent English Roman Catholic historian and publisher Douglas Jerrold argued in his The Lie about the West: A Response to Professor Toynbee's Challenge that he had unjustly underestimated the endurance of Christian civilisation and failed to recognise its inherent value as the source of many fundamental values which should not be surrendered to supposedly inexorable historical processes.
\end{abstract}

\section{INTRODUCTION}

The rôle of Christianity in the history of the interaction of cultures has long been debated by historians, missiologists, and others. In 1952 the British Broadcasting Corporation became the arena for one such dispute when the renowned English historian of civilisations, Arnold Toynbee, seeking to help his compatriots understand why much of the world had assumed hostile attitudes towards not only the United Kingdom but "the West" in general, delivered the annual Reith Lectures in which he argued that western Europe, including its Christian religious identity, was merely reaping the bitter fruit of its imperialist behaviour in recent centuries. For at least 400 years, this distinguished academic argued, the West had aggressively subordinated eastern Europe and Asia in particular and imposed aspects of its civilisation on

1 Prof. F. Hale, Department of English, University of Stellenbosch. 
those regions. Instead of fully recreating them in its own image, however, it had sown the seeds of animosity. In the twentieth century, "the world", in his nomenclature, was reasserting itself against Western hegemony. This general response was manifesting itself in inter alia wars of independence, Marxism and religious nationalism which challenged prevailing attitudes of self-righteousness and smugness allegedly characteristic in the West. In the end, Toynbee believed as the sun was gradually setting on the British Empire, the reaction could also spell the end of Western domination of the globe. He urged his audience to take a more critical view of their legacy of imperialism and thereby understand why, in the eyes of the Russians, Moslems, Hindus, Chinese, Japanese, and various other peoples, "the west ... has been the arch-aggressor of modern times." ${ }^{2}$ His six lectures, broadcast at weekly intervals in November and December 1952, were printed serially in the BBC's weekly periodical The Listener under the titles "The World and the West: Russia", "The World and the West: Islam", "The World and the West: India", "The World and the West: "The World and the West: the Far East", "The Psychology of Encounters", "The World and the Greeks and Romans". They were subsequently published as a book. ${ }^{3}$

Coming during a particularly chilly phase of the Cold War when American forces were pitted against North Koreans backed by divisions of Mao's army and when the Soviet Union, with Stalin and his cohort still firmly in control, had recently developed nuclear weapons, Toynbee's plea was met with a storm of protest. Immediately after the conclusion of his six broadcasts, the editor of The Listener wrote in a leading article that no previous series of Reith Lectures had occasioned "so much interest and controversy" as those delivered by the eminent historian. He mused that one factor contributing to both Toynbee's overarching theme and the mixed reactions to it may have been that the speaker had come to maturity during the so-called "Age of Guilt" and that many people of his generation believed that religion offered the only ultimate "hope and consolation" during "the coming

2 Arnold Toynbee, "The World and the West: Russia", The Listener XLVIII, no. 1238 (20 November 1952), p. 839.

3 Arnold Toynbee, The World and the West (London: Oxford University Press, 1953). 
Atomic Age", whereas many of the younger detractors were products of a more secularised era and had less sympathy for Russia and the other lands whose anti-Western attitudes Toynbee had sought to elucidate. ${ }^{4}$ In fact, as we shall see shortly, the dispute had only begun. It continued into the mid-1950s, and much of it pivoted on specifically Christian aspects of Western civilisation.

The exchange is relevant and illuminating to the study of church history because in microcosm it sheds light on radically differing attitudes towards and perceptions of the part that Christianity, in tandem with a politically and militarily dominant civilisation, has played in the disharmonious interaction of cultures. In the present article I shall explore the religious crux of the debate by focussing primarily on the reaction to Toynbee of a rival historian, Douglas Jerrold (1893-1964), a staunch and notoriously strident Roman Catholic whose understanding of the birth and continuity of European civilisation reflected what was then virtually an article of faith among many conservative intellectuals in his denomination, at least in the United Kingdom. Notwithstanding the woes that had plagued the heavily indebted British economy in the wake of the Second World War and the gradual contraction of the Empire (from which India and Pakistan had gained independence in 1947 and across other regions of which winds of change were perceptibly blowing), the 1950s were a time of considerable optimism in the United Kingdom, as prosperity was evidently returning and public religious life seemed to be enjoying its final salad days before the eroding forces of secularisation became evident in the 1960s. This was the case not least with regard to the Roman Catholic Church, which established scores of new parishes during the post-war years, ordained a large number of priests to serve them, and continued to maintain its network of parochial schools. It was in this climate of selfassuredness that Jerrold, a long-time advocate of British imperialism and champion of the Catholic cultural legacy in Europe, crossed swords with Toynbee. Enhancing the contextual significance of this brief investigation, I shall also consider a small selection of other contemporary responses to Toynbee's Reith Lectures.

4 "The World and the West", The Listener XLIX, no. 1245 (8 January 1953), p. 50 (editorial). 


\section{THE CONTROVERSIAL ARNOLD TOYNBEE}

In the early 1950s Toynbee was at the zenith of his long and distinguished academic career. Born in London in 1889, he had gone up to Balliol College at the University of Oxford in 1907 and excelled in classical languages and humanities, compiling a record which led him to be hired as a tutor in ancient Greek and Roman history at his alma mater. Deepening his first-hand geographical and cultural knowledge, Toynbee walked through much of Greece and Italy in 1911 and 1912 and also studied at the British School of Archaeology in Athens. After returning to England, he accepted in 1919 a teaching appointment in Byzantine and modern Greek language, literature, and history at the University of London, a post he held for five years before beginning a thirty-year stint as director of studies at Chatham House, the Royal Institute of International Affairs. This prestigious position entailed editing the annual Survey of International Affairs but allowed Toynbee to spend a great deal of time as a prominent Liberal, and liberal humanist, thinker writing inter alia regular columns for the Manchester Guardian and the Observer while pressing ahead with his grandiose historiographical projects. ${ }^{5}$

The pivotal one of these was his magisterial synthesis A Study of History, the twelve-volume suite which Oxford University Press began to publish in 1934. In that massive and highly controversial work, Toynbee developed his "challenge and response" theory of the history of civilisations, a notion which underlay the central thrust of his Reith Lectures. During the First World War this young historian, much of whose attention was focussed on the ancient Mediterranean world, perceived European civilisation undergoing a general crisis which echoed the experience of Greek civilisation at the time of the Peloponnesian War in the fifth century B.C. Thus was conceived Toynbee's comparative, cyclical understanding of history in which he believed certain laws were guiding the destinies of successive civilisations. By the time he undertook the writing of his Lebenswerk, professional historiography

5 Louise Orr, "Toynbee, Arnold Joseph”, in Lord Blake and C.S. Nicholls (eds.), Dictionary of National Biography, 1971-1980 (Oxford and New York: Oxford University Press, 1986), pp. 857-858. 
in the United Kingdom and Europe generally had developed in a variety of directions which multiplied as Toynbee added volume after volume to his series. Inevitably, many of his colleagues at home and abroad, such as Professor Hugh Trevor-Roper of Oxford and Professor Pieter Geyl of the University of Utrecht categorically rejected the cyclical approach outright. To this Dutch scholar, Toynbee's general approach to history was artificial and unempirical. Indeed, in 1954 he went so far as to deny that Toynbee was a historian at all, calling him instead a "prophet" whose "prophecy" was "a blasphemy against Western Civilization". ${ }^{6}$ Others opponents chipped away at his findings by pointing to numerous errors of fact in his prodigious output.

The minutiae of the historiographical controversies in which Toynbee had been embroiled before his Reith Lectures need not concern us. What is essential to the present topic, however, is the fact that his understanding of the vulnerability and transitoriness of all civilisations, including that of Christian Europe, conflicted with the conviction of many European Christians that their world, in which the church had occupied a central place and provided immeasurable cultural and moral guidance for more than 1500 years, was ordained of God as the enduring summit of world history. Neither Toynbee's accusations of the general culpability of the West for global violence nor his belief in the temporality of European hegemony fitted the mind-set of such adherents. These eventualities were, for many such people, virtually imponderable. Toynbee, however, whom one of his biographers has called "a deeply religious agnostic", 7 had no such commitment to the notion of a permanent Christian civilisation. Nor did he feel compelled to depict Christianity in terms harmonious to his listeners who adhered to that religion. Indeed, in his first lecture, he acknowledged that listeners might be "a little indignant" to hear him refer to theirs as a "post-Christian society". 8

6 P. Geyl, Debates with Historians (Groningen: J.B. Wolters, 1955), p. 178.

7 Orr, “Toynbee, Arnold Joseph”, p. 858.

8 Toynbee, "The World and the West: Russia", p. 839. 


\section{THE CRUX OF TOYNBEE'S REITH LECTURES}

Toynbee's lectures were not a condensed version of his multi-volume A Study of History, but they clearly reflected his overarching theory of challenge and response, and that fact inevitably set many listeners against him. Further stacking the deck against a hospitable reception of his lectures, their format and purpose in seeking to reach a very broad, popular audience led Toynbee to cast his remarks in a mould which sacrificed precision in the interest of sweeping generalisations which limits of time prevented him from adequately documenting or qualifying. His conceptual framework, moreover, was in places imprecise, not least with regard to his categories "the world" and "the West", and he arguably did not sufficiently underscore that many of his remarks were representations of generalised perceptions and attitudes of inter alia Russians and Asians towards the West rather than his own studied judgments of the detailed contours of history. To be sure, in the opening remarks of his first lecture Toynbee sought to clarify his purpose. "Let us try, for a few minutes, to slip out of our native western skins and look at this encounter between the world and the west through the eyes of the great non-western majority of mankind," he pleaded. By doing so, he hoped, they could begin to understand the reaction against their nearly global domination. ${ }^{9}$ This plea went unheeded in some quarters, and Toynbee committed, in the opinion of his critics, numerous historiographical pratfalls at which they quickly pointed fingers. In our present consideration we shall not be concerned with these minutice, however, but shall instead concentrate on certain themes in the Reith Lectures which prompted attacks from what Jerrold regarded as a Christian viewpoint.

Perhaps none of these riled Jerrold and like-minded believers in the United Kingdom more than Toynbee's insistence that Christian domination of their civilisation was a thing of the past. Acknowledging that Russia had entered a "post-Christian" phase of its history, he declared that "our western community" had similarly become "a post-Christian society" and realised that this verdict would be met with surprise and "a little" indignation. To this historian, who sought to maintain a posture of neutrality vis-à-vis the place of Christianity

Ibid. 
in the West, it was evident that since the Enlightenment "we too have been drifting further and further away from our western Christian tradition." Many of the external forms of that tradition, such as buildings and holidays, were still intact, but, as he put it, "if we look into our hearts, we shall see how far we too have moved away from our Christian past." Secondly, Toynbee inevitably antagonised many listeners by generally agreeing with the perception widespread in Russia, Asia, and elsewhere that his own civilisation bore a heavy burden of guilt. "And certainly the world's judgment on the west does seem to be justified over a period of about four and a half centuries ending in 1945," he pronounced. "In the world's experience of the west during all that time, the west has been the aggressor on the whole ..." Thirdly, in his zeal to explain why resentment towards the West had developed in other parts of the world, Toynbee dealt only briefly with the fact (which his critics were quick to adduce as countervailing evidence) that Russia and other countries also had gallons of imperialist blood on their hands. ${ }^{10}$

\section{GENERAL CHRISTIAN REACTIONS TO TOYNBEE}

Toynbee's lectures ruffled the feathers not only of Britons who perceived the world in terms of a comprehensive Cold War duality separating East and West but also those of many Christians who for a variety of reasons resented what they perceived as either an attack on their faith or at least a failure to recognise its distinctiveness and contributions to the well-being of humanity. Representing many denominations, these believers voiced their dissent in The Listener and other public fora long before Jerrold wrote his book against Toynbee.

Katherine Atholl, for instance, known as the "Red Duchess" because of her sometimes radical political views, rejected what she regarded as Toynbee's severely biased and myopic perception of the place of the West and, more particularly, of Christianity in world history. Indeed, she argued quite explicitly that the symbiosis of British imperialism and missionary endeavours had bestowed untold benefits on many foreign lands. Atholl lamented that Toynbee had said 
nothing of all the great work and education and improvement in treatment of health, brought to "the world" for some generations back by devoted missionaries from the west, and, in the case of all such countries under British rule, also greater internal peace and justice, and, anyhow, some improvements in standards of living.

On the home front, she dismissed Toynbee's use of the term "postChristian society", an appellation which, it might be added, struck many other British observers as premature in the 1950s. Atholl allowed that not all churches were filled on every Sunday but ascribed the many empty pews to a lack of homiletical brilliance and to a surfeit of secular distractions rather than to disaffection with Christianity. She thought that her own time was, in its way, a zenith of applied faith: "But when," Atholl asked,

has the world known so much of the care for the weaker or suffering neighbour enjoined on us by its Founder as the very essence of Christianity, as is to be fond in the west today ${ }^{11}$

Russian emigré Gleb Kerensky responded from a quite different perspective in challenging Toynbee's line of demarcation between "the world" and "the West". He did so on a partially religious basis. With regard to the Russians, he explained,

any suggestion that their country is not part of the general surge of white men and Christians (or Marxists!) civilising the rest of the world would create more surprise in Moscow than in Stockholm or Vienna, because Russia is an old-fashioned colonial power with a very clearcut popular attitude to its "eastern" subjects - i.e. that while there is nothing basically inferior about them, they are "heathen" until they adopt Christianity (or Marxism!) and entirely ignorant until they learn Russian. ${ }^{12}$

\section{THE LEGACY OF HILAIRE BELLOC}

Jerrold's hostility to Toynbee's interpretation of the role of the West in modern history was virtually inevitable, given what might be advisedly called Jerrold's faithful indebtedness to a perception of Eu-

11 Katharine Atholl (London) to The Listener, undated, in The Listener XLVIII, no. 1239 (27 November 1952), p. 893.

12 Gleb Kerensky (Rugby) to The Listener, undated, in The Listener XLVIII, no. 1239 (27 November 1952), p. 895. 
ropean history he had inherited from his principal mentor, Hilaire Belloc, who in turn had been profoundly influenced by the works of the great nineteenth-century French historian, Numa Denis Fustel de Coulanges (1830-1889). A Parisian by birth, he had graduated from the École Normale Supérieure in 1853 and continued his studies at the French School in Athens. Fustel de Coulanges became a professor of history at the University of Strasbourg in 1860. Returning to Paris in 1870, he lectured at the École Normale, and in 1878 was appointed to the Sorbonne's first chair of medieval history, a post he held until his death. Fustel de Coulanges' pivotal place in the annals of French historiography rests chiefly on two of his studies which reflected his dual interests in, respectively, ancient and national history. In La Cité antique (1864) he argued that religions beliefs had moulded the political and social institutions of Greece and Rome. Approximately a quarter-century later, during a period of intensive anti-German sentiment among many of his compatriots, he wrote his six-volume work, L'Histoire des institutions politiques de l'ancienne France (1888-1892), in which he adduced a massive amount of evidence to support his thesis that French feudal institutions were Roman rather than Teutonic in origin. Latin civilisation, in other words, had survived the collapse of the Roman Empire largely intact and shaped the course of much of western European history. The Germanic contribution, concomitantly, was minimal.

Hilaire Belloc (1870-1953) provided a personal bridge across which Fustel de Coulange's interpretation could traverse the English Channel and take root in the United Kingdom where, however, it never went unchallenged among historians and others who continued to take their stand on the primacy of the Anglo-Saxon roots of their national culture while acknowledging that Norman immigration, especially after the Battle of Hastings in 1066, had also left deep imprints on the terrain of British civilisation. Born in France of French and English parents, Belloc had been taken to England as a child and raised bilingually, served in the military of the land of his birth, studied at the University of Oxford, and been elected a Member of Parliament as a Liberal before becoming disillusioned with democracy and modernity in general early in the twentieth century. Belloc subsequently pursued a career as a highly prolific historian as well as a novelist and 
editor. An exponent of conservative Roman Catholicism, he exercised a profound influence on a generation of his co-religionists who accepted his historiographical creed. ${ }^{13}$

A detailed presentation of Belloc's historiographical framework lies outside the scope of the present study. We shall therefore limit it to a statement of his agreement with his mentor Fustel de Coulanges. Quite in harmony with him, Belloc argued in one volume after another that the cultural legacy, broadly defined, of the Roman Empire had survived the collapse of centralised government and bequeathed itself to much of Europe, thus exercising immeasurable hegemony until the time of the Reformation. The principal guide and inspiration of this romanità was no longer the administration in Rome but rather the Roman Catholic Church, which served as the bonding agent for Europe for more than a thousand years. That massive wing of Christianity had become inextricably intertwined with the cultural milieu it had fostered, to create European civilisation, which Belloc and his disciples thought was virtually synonymous with Christian - and more specifically Roman Catholic - civilisation. The latter, he insisted unabashedly, constituted the essence of the former. As he expressed it in his book Europe and the Faith,

... there is no such thing as a Catholic "aspect" of European history. There is a Protestant aspect, a Jewish aspect, a Mohammedan aspect, a Japanese aspect, and so forth. For all of these look on Europe from without. The Catholic sees Europe from within.

Belloc expressed the underlying postulate of his historiographical approach succinctly in a brace of pithy and frequently quoted dicta: "I say again, renewing the terms, The Church is Europe; and Europe is The Church" and "The Faith is Europe. And Europe is the Faith." His nostrum for the crisis of the continent in the early twentieth century was correspondingly simple: "Europe will return to the Faith, or she will perish." ${ }^{14}$ Belloc carried his commitment to the heritage of romanità to his adopted homeland in unambiguous terms. "England

13 The point is central to Robert Speaight's biography, The Life of Hilaire Belloc. London: Hollis \& Carter, 1957.

14 H. Belloc, Europe and the Faith (London: Constable and Company Limited, 1920), pp. 3, 6, 331 . 
begins as a province of the Roman Empire," he declared in the opening paragraph of his A Short History of England.

All our institutions, instruments, laws, building, and writing derive from the Roman civilization, of which we are still a department. ${ }^{15}$

Douglas Jerrold carried the torch further, arguing the same point, to the great irritation of many professional academic historians who attributed much of the formation of English culture to Anglo-Saxon influences, in several books which he wrote beginning in the 1930s, such as England ${ }^{16}$ and Britain and Europe 1900-1940. ${ }^{17}$ The same commitment to this Bellocian tenet is embodied in his non-fictional booklength essay The Necessity of Freedom ${ }^{18}$ and underlies his Ruritanian, antirevolutionary novel of 1930, Storm Over Europe. ${ }^{19}$ To Jerrold, no less than to Belloc, the warp and woof of European civilisation lay in Christianity, more specifically Roman Catholicism, and, during the Cold War, he saw the salvation of Europe in no small measure in the envisaged return of the continent to its Christian roots when threatened by what he clearly perceived as a lethal, anti-Christian ideology, namely Marxism as institutionalised in the Soviet Union.

\section{JERROLD'S BELLOCIAN CRITICISM OF TOYNBEE'S GENERAL APPROACH}

Jerrold's book of 1954, The Lie about the West: A Response to Professor Toynbee's Challenge, was his principal riposte to the 1952 Reith Lectures, and this work prompted a new phase in the public debate about the magisterial professor's views as he had expressed them on the BBC. Despite their many differences, the two men shared certain overlapping conceptions of the general course of history. One of them was a belief that it was governed by laws. As Jerrold had remarked in his preface to his translation of René Quinton's Soldier's Testament,

15 Hilaire Belloc, A Shorter History of England (London: George G. Harrap \& Co. Ltd., 1934), p. 21.

16 Bristol: Arrowsmith, 1935.

17 London: Collins, 1941.

18 Jerrold, Douglas. The Necessity of Freedom. Notes on Christianity and Politics (London: Sheed \& Ward, 1938).

19 London: Ernest Benn, 1930. 
The task of historians to-day is to search for Newtonian laws which explain all the facts coherently. That search is barely begun, and it is impeded at every turn by the persistent attempts of progressmongers to interpret some facts and pervert others to fit in with an assumption wholly unscientific, and as much a matter of blind and unreasoning faith as the assumptions shattered by Copernicus, Gallileo [sic] and Kepler. ${ }^{20}$

Another postulate, intimately related to this, was that in general history was cyclical (though of course Jerrold saw in Christian Europe a divinely inspired exception to the overarching pattern). As he wrote in his response to Toynbee,

the history of man is now known to be the history not of a slow and laborious ascent, but of successive civilizations rising, maturing, and declining.

In conscious rejection of a fundamental tenet of both "the so-called 'Enlightenment'" and much thought of the Victorian era, Jerrold denied the

theory of natural progress, which by the end of the nineteenth century had come to be generally accepted by all except the believers in original sin.

Instead, he praised, albeit with qualification, Oswald Spengler's treatise, which had been published in two volumes as Der Untergang des Abendlandes in 1918 and 1922 and appeared in an English translation under the title The Decline of the West in 1926 and 1928 and been roundly criticised by some British historians, as it had been by many of their German counterparts. Undaunted, Jerrold acknowledged that Spengler's work embodied some "positive absurdities" but argued that it nevertheless marked a turning point in historical thinking.

What we must all study to-day is not the law which governs the progress of societies, but that which appears to dictate their decline.

In Jerrold's interpretation of the Reith Lectures, however, the liberal Toynbee had actually clung to the progressive view of history and, unable to dismiss the gradual rise of Russian power, had "ral-

20 Douglas Jerrold (ed. and trans.), Soldier's Testament. Selected Maxims of René Quinton (London: Eyre and Spottiswoode, 1930), pp. 43-44. 
lied the dispirited believers in progress" by presenting the relative decline of the West as "a step on the upward path" of the world generally. To Jerrold, of course, it was absurd to see evidence of this in the Stalinist Soviet Union; that country's British acolytes could defend it only by regarding error on a massive scale as progress. ${ }^{21}$

A cornerstone of Jerrold's argument was his belief, held simultaneously with his commitment to a cyclical view of history, that Christianity has bestowed a unique heritage on Europe and, by extension, much of the world. This conviction, undoubtedly inherited in part from Belloc but also reflecting a widely held view, underlay his criticism of Toynbee, which cannot be understood apart from it. That historian's theory of the vulnerability of all civilisations, Jerrold argued, was simply incompatible with his own perception how Europe had developed during the past 1900 years. He asked,

And does it not make nonsense of a story which is plain enough to read, which tells us, in fact, why and in what respect the Christian civilization is as unique as it claims to be? ${ }^{22}$

Without mentioning Belloc by name, Jerrold revealed lucidly his indebtedness to his Anglo-French mentor and stressed his fealty to the same precepts which had guided Belloc's portrayal of the relationship of Christianity to European civilisation. Much of Toynbee's inspiration for his overall understanding of world history sprang from his perceptions of similarities between the decline of the GraecoRoman civilisation and in recent times, that of the West. To Jerrold, such a comparison was inherently illegitimate, because he, following Belloc, did not believe that Graeco-Roman civilisation had actually declined, much less disappeared, at least not in the same sense that many other civilisations had come to grief. Instead, lucidly reflecting a fundamental Bellocian tenet, he declared that Roman culture survived the break-up of the Roman imperium largely intact and continued to shape much of European life, though now under the aegis of the Church of Rome. Jerrold observed

21 Douglas Jerrold, The Lie about the West. A Response to Professor Toynbee's Challenge (J.M. Dent \& Sons Ltd, 1954), pp. 19-26.

22 Jerrold, The Lie about the West, p. 27. 
City life and village life within the confines of the old empire were never destroyed by the Gothic conquerors. The Christian sees were continuously occupied except in Britain and Spain. It was because the Roman Church and Church government survived elsewhere and because the apostolic succession was elsewhere preserved, not because the secular empire of the West collapsed, that Christian civilization was preserved on the mainland of Europe, came back eventually to Britain and Spain, and spread to Germany. ${ }^{23}$

The resulting amalgam of Graeco-Roman and Christian elements, in his view, had bestowed on Europe a cornucopia of blessings, including

such august concepts as the rule of law, the rights of conscience, the right of free speech and free association, the right to life, liberty, and the pursuit of happiness, the right, sacred above all other rights, of men to save their souls by fulfilling the purpose of their being as free moral agents in correspondence with Divine Grace ... ${ }^{24}$

\section{JERROLD'S CRITICISM OF RUSSIAN EXPANSION AND COMMUNISM}

Writing from the icebox of the Cold War and against the backdrop of the Soviet Union's occupation of vast areas of eastern Europe during and immediately after the Second World War, the intensely anticommunist Jerrold aimed much of his artillery at what he regarded as Toynbee's naïve, erroneous, and exculpatory attitude towards Russian expansionism. It was simply unhistorical, he thought, to portray Russia as the innocent victim of Western imperialistic aspirations since the Middle Ages. Jerrold countered,

The six centuries of Western aggression against Russia are in fact the six centuries which have witnessed the expansion of Russian domination from the small landlocked state of Muscovy in the fourteenth century to the great empire which we now know - infinitely the largest continental empire known in history. ${ }^{25}$

Toynbee was by no means alone in underestimating the magnitude and potential consequences for Europe and other parts of the world of this general tendency, he opined, "because until 1945 the real danger

23 Jerrold, The Lie about the West, pp. 34-35.

24 Jerrold, The Lie about the West, p. 4.

25 Jerrold, The Lie about the West, pp. 9-10. 
to Western civilization from Russia was not fully appreciated by the Atlantic powers." Jerrold himself had, of course, and his defensive mentality darkened further still his view of Toynbee's sympathetic attitude towards non-Western cultures. This erstwhile military historian's own position apparently incorporated the view that whoever is not for us is against us. With primary reference to the Soviet Union, he thus declared bluntly:

In The World and the West pessimism as to the future of Christian civilization is carried to the point where listeners are, it seems to me, urged to leave the sinking ship, to see the enemy's point of view, and to meet him in the gates before he storms the citadel. ${ }^{26}$

A subsequent section of the argument in The Lie about the West reveals how important this was in Jerrold's dissatisfaction with Toynbee. One had to take sides unambiguously in the contemporary struggle for world power, he thought, and align oneself with either Christianity or the notion of the collectivist state.

It is not possible, of course, for a Christian to be a theoretical Communist, because Communism, of its essence, makes the family subordinate to the State, makes man a function of the machine, and denies to the family that element of economic independence and free choice which is necessary if men and women are to be free moral agents.

But that decision was one which Jerrold thought the detached Toynbee had avoided. Jerrold wondered "what is the Professor's attitude to Communism, as such" because he found no clear answer in the Reith Lectures. With unveiled dismay he quoted Toynbee that "Communism's success, so far as it has gone, looks like a portent of things to come." To Jerrold, who as a disciple of Belloc made no bones about his commitment to Christian civilisation and who unabashedly wrote history books in its defence, it seemed "curious" that his adversary had "carefully refrained from expressing his own opinion" about the ultimate desirability of communism. ${ }^{27}$

26 Jerrold, The Lie about the West, pp. 3, 25-26.

27 Jerrold, The Lie about the West, pp. 46-47. 


\section{TOYNBEE'S DEFENCE}

Toynbee did not take the scholarly and semi-scholarly impugning of his professional competence lying down but put up a spirited if restrained defence in The Times Literary Supplement, especially after an anonymous reviewer of the published version of the Reith Lectures added his voice to Jerrold's by challenging him on a variety of points. He acknowledged that "I have not expressed my beliefs, expectations and hopes clearly in my Reith Lectures" but insisted that he had done so in the first four volumes of A Study of History. One fundamental misunderstanding which he sought to dispel was that he had suggested on the BBC that the West was "likely to be converted to Communism". In response to a challenge issued by a reviewer of Jerrold's book to predict what kind of religious conversion the West might make, Toynbee hazarded what he admitted was a "guess" that it could be to a faith which, "like Mahayanian Buddhism, Mithraism and Christianity, calls on us to worship a god who is not a deification of our human selves". He generalised dispassionately that

since the close of the seventeenth century we Westerners have been progressively substituting for Christianity one form of man-worship: a cult of individual liberty on a secular, instead of a Christian, basis.

For that matter, Toynbee thought that communism's days were also numbered, possibly to be replaced by some kind of amalgamated religion:

I guess that both the west and the world are going to turn away from man-worshipping ideologies - Communism and secular individualism alike - and become converted to an Oriental religion coming neither from Russia nor from the West. I guess that this will be the Christian religion that came to the Greeks and Romans from Palestine with one or two elements in traditional Christianity discarded and replaced by a new element from India.

He hoped that "this avatar of Christianity will include the vision of God as being Love" and hoped that it would

discard the other traditional Christian vision of God as being a jealous god, and that it will reject the self-glorification of this jealous god's "Chosen People" as being unique.

Toynbee thought that India could contribute to this hybrid faith 
with her belief (complementary to the vision of God as Love) that there may be more than one illuminating and saving approach to the mystery of the universe. ${ }^{28}$

\section{THE CRITICISM OF MARTIN WIGHT}

One of the most devastating responses to Jerrold's attack on Toynbee came from Martin Wight, a highly learned historian at the London School of Economics. Writing in The Times Literary Supplement, this practising Christian challenged the reviewer in that periodical who had described Jerrold's book as a "pre-eminent" in terms of "logical rigour" and "historical judgment". To the dissenting Wight, The Lie about the West was a work of "tendentious history" in which Jerrold had gravely misrepresented Toynbee. Underlying his reaction was his dislike of Jerrold's abundant self-confidence, which Wight thought had repeatedly tempted him to venture out on the thin ice of speculation beyond the empirical foundation of his arguments, and Jerrold's insistence in forcing historical complexities into the framework of his simplified historiographical theories. Wight did not deny that the same might be said of Toynbee but thought that

arbitrary selection and dogmatic assertion are Mr. Jerrold's method of historical discussion, and he shows an old-fashioned positivist belief in "the facts" (i.e., his facts) as something separable from their interpretation.

He offered several indicting examples of this, one of the most cogent of which related to the history of Russia, a country which the Cold Warrior Jerrold had never found it possible to discuss dispassionately. Pecking away at a vulnerable wound, Wight quoted his assertion that czarist expansionism had been a constant historical theme, "marked only by one set-back in 1918". This, as Wight pointed out, was a patently absurd oversimplification which ignored such recent matters as the Russian cessions of southern Bessarabia in 1856 and of southern Sakhalin in 1905. Even more seriously, he emphasised, was Jerrold's amnesia regarding the crucial half-century following the

28 Arnold Toynbee (London) to The Times Literary Supplement, undated, in The Times Literary Supplement no. 2,724 (16 April 1954), p. 249. 
death of Ivan the Terrible, when Poland conquered much of western Russia and the loss of the Baltic provinces to Sweden. ${ }^{29}$

Wight was also riled by what he perceived as a fundamental lack of fairness on Jerrold's part in responding to Toynbee's broadcasts. "The Reith Lectures are a medium for presenting conclusions to a wider public rather than for argument and evidence. Dr. Toynbee's lectures reproduced the themes expounded at length in A Study of History," he noted.

If Mr. Jerrold is familiar with A Study of History, it is the more inexplicable that he does not admit to his readers that Dr. Toynbee's theory of civilizations, and his delineation of particular civilizations (against which Mr. Jerrold makes some telling criticisms) have been elaborately formulated with a great apparatus of scholarship and will require a correspondingly massive refutation.

Instead, Wight lamented, Jerrold had focussed exclusively on the popularised version of certain themes which were incorporated in the Reith Lectures and thrown a punch below the belt by accusing him of engaging in "an eleventh-hour effort to salvage the materialist case against the Christian conception of society". These and other considerations led Wight to conclude that

even those who happen to share Mr. Jerrold's views on Christianity rather than Dr. Toynbee's may think that Mr. Jerrold's polemical methods lower the standards of controversy which it is a general interest to uphold. ${ }^{30}$

\section{A RABBINICAL DEFENCE OF JERROLD AND CHRISTIAN CIVILISATION}

Improbably, one of the most spirited and, from a theological viewpoint, carefully reasoned defences of Jerrold came from the pen of Ignaz Maybaum, a Reformed rabbi in London. A native of Vienna, he had studied at the universities there and in Berlin and served as a rabbi in Bingen, Berlin, and Frankfurt an der Oder during the 1920s and 1930s. In the latter half of the 1930s Maybaum had witnessed

29 Martin Wight (unspecified provenance) to The Times Literary Supplement (undated), in The Times Literary Supplement no. 2,727 (7 May 1954), p. 297.

30 Ibid. 
the mounting persecution of Jews in the Third Reich and been briefly incarcerated in a concentration camp. He emigrated to London in 1939. Appointed rabbi at the Edgware and District Reform Synagogue in 1948, he served there until retiring in 1963. Maybaum sought to foster interfaith understanding in the United Kingdom and indeed devoted much of his ministry to such reconciliation. Illustrative of this concern, in his study of 1973, Trialogue between Jew, Christian and Muslim (1973) he concluded that all three were authentic monotheistic religions. ${ }^{31}$

This Jewish clergyman perceived in Toynbee's interpretation of global history an echo of Oswald Spengler's understanding of the Occident and the latter in terms of its analogous relationship to different emphases in the New Testament. "Spengler's Decline of the West is - in secular form - an exposition of a pauline Christianity without prophetic messianism or even of a marcionite Christianity rejecting this form of messianism altogether," he reasoned. By contrast,

the West is petrine civilization; in petrine Christianity the messianism of the biblical prophets is a strong factor. But Spengler and Toynbee regard the missionary zeal of petrine civilization as mere political and economic self-interest.

The emphasis on apocalypticism, unmerited grace, and predestination inherent in Pauline thought conflicted with Maybaum's understanding of the ongoing validity of certain religious values which he found common to the Old Testament and the New and which, in his view, had imbued in Western civilisation with an understanding of human worth which must be preserved. He therefore found particularly lamentable Spengler's deprecation of Western democracy's elevation of "the common man' to full dignity in a technological civilization". This rabbi argued the case for the union of Christian and European civilisation more explicitly than any other participant in the debate over Toynbee's pessimistic view of the West's future:

Western civilization is superior to the civilization propagated by the Kremlin. I ignore the story that Russia is a country in which 200 million Russians are believers of Marxist philosophy. The Ortho-

31 Rabbi Michael Leigh, "Rabbi Dr Ignaz Maybaum”, The Times, 2 April 1976, p. 16. 
doxy is Christianity without freedom. Only in the petrine Christianity of the West is freedom inseparable from Christianity. The johannine Christianity of Russia is near to Islam, which is also a religion without freedom. Western civilization is also superior to Buddhist and Confucian Asia, where man is seen not as the prophets saw him, chosen in his uniqueness, but only as a particle of the collective and not above the level of mere nature.

Maybaum's own recent experience with the Third Reich reinforced his commitment to biblical values which he believed must be preserved in Western civilisation for the benefit of humanity in general. Carefully avoiding sensationalism, he pointed as an example of the baneful potential impact of what he perceived as the Toynbee position to the case of the renowned theologian at the University of Berlin, Adolf von Harnack. Maybaum stressed that this German churchman was "not less a Liberal than the Englishman Toynbee" and that in his study of the second-century Christian Marcion he had rejected "exactly those parts of the Old Testament which seem also to Dr. Toynbee no longer acceptable". A few years after Harnack's death in 1930,

his view about prophetic Judaism became the ideology of Germany's rulers: they forced the Church to preach Christianity according to Marcion.

To Maybaum, it seemed clear that Toynbee was in effect advocating something akin to "Marcionite Christianity" and that if the London historian's position were followed, it would "enervate every civilization" as it had "led Germany to her doom". Rejecting the attitude that history must run its course according to certain patterns, he warned against the dangers inherent in such pessimism:

Spengler and Toynbee view civilization without the discernment of the prophets who made a distinction between right and wrong, and therefore, between the one lasting and the other transient civilizations.

The rabbi offered specifically religious advice to obviate that eventuality:

To prevent Man the Creator from promethean hubris neither Marcion, nor Indian philosophical nihilism which Toynbee recommends, should be preached but the hope inherent in Jewish-Christian teaching. 
The West had to preserve its biblical legacy of the relationship between God and mankind. The understanding of history enshrined in the Bible was an antidote to the twentieth-century notion that the specific nature of a civilisation was unimportant in itself, that civilisations are simply "given to inevitable death when summer has gone and winter is here". Maybaum propounded as the essential alternative
the idea of election - man chosen by God to serve in the holy cause - the history of man is changed irrevocably. History is no longer the kaleidoscope in which innumerable patterns change in- numerably. History is under a law, the Law of God, and history has a goal, the kingdom of God. ${ }^{32}$

His line of thinking was, for the most part, in harmony with what Jerrold had argued against Toynbee. The essential difference was that Maybaum saw the central thrust from a more inclusive religious perspective, whereas Jerrold had explicitly sought to challenge Toynbee on the battlefield of historical facts and manifested both a Cold War mentality and his Bellocian understanding of the virtual identity of European Catholicism and Western civilisation.

\section{CONCLUSION}

The verbal duel between Toynbee and Jerrold did not prove fatal to either foe. Toynbee remained an immensely respected historian, though one with a wide array of professional detractors. Jerrold was clearly in the twilight of his career; his productivity had been waning, although he, too, continued to write history for several more years. When one considers his position in its own historical context, however, it is obvious that the Bellocian interpretation of European history had largely been eclipsed by the 1950s. Even for non-Marxists, it seemed far too simplistic to attribute the complex unfolding of Europe merely, or even primarily, to the impact of Roman Catholicism, important though that legacy was in the eyes of historians across much of the ideological spectrum, at least when other determinants were overlooked. Owing to a rapid decline in his health, Belloc him-

32 Ignaz Maybaum (London) to The Times Literary Supplement, undated, in The Times Literary Supplement no. 2, 726 (30 April 1954), p. 281. 
self had been largely inactive since the early 1940s, and he died seven months after Toynbee broadcast his Reith Lectures.

The principal significance of the debate arguably lies in the light it sheds on conflicting mentalities during an era of British national decline as the sun was setting on the Empire and fears were evident that communist and Asiatic societies would replace British and Western hegemony. Clearly, Roman Catholics like Jerrold continued to fear, as they had feared during the Spanish Civil War of the late 1930s, that they might be living near the terminus ad quem of the Christian European era, and with the Cold War chilling any thought of compromise, they believed that no concessions should be made to imply the divine legitimacy of other ideological systems and cultures.

Keywords

History of civilisations

Arnold Toynbee

Douglas Jerrold

Christian civilisation

Western imperialism
Trefwoorde

Geskiedenis van beskawings

Arnold Toynbee

Douglas Jerrold

Christelike beskawing

Westerse imperialisme 